\title{
Pattern of Thyroid Cancer and Its Associated Factors Among Thyroid Patients Underwent Thyroidectomy at Jimma Medical Center, Southwest Ethiopia; A Four Years Retrospective Review
}

\section{Bilisuma Mulatu}

Jimma Institute of Health Sciences: Jimma University

Yadene Michael

Jimma Institute of Health Sciences: Jimma University

\section{Seifu Alemu}

Jimma Institute of Health Sciences: Jimma University

Wondu Reta Demissie ( $\square$ majore04@gmail.com )

Jimma Institute of Health Sciences: Jimma University https://orcid.org/0000-0002-3888-0774

\section{Research}

Keywords: Thyroid disease, Patterns, malignancy, Histopathology, Associated factors, JMC, Ethiopia

Posted Date: September 15th, 2020

DOl: https://doi.org/10.21203/rs.3.rs-73562/v1

License: (c) (1) This work is licensed under a Creative Commons Attribution 4.0 International License. Read Full License 


\section{Abstract}

Background: Thyroid cancer is the most common malignant disease of endocrine system and its incidence is rapidly increasing globally (about three to four times higher among females and accounts the sixth most common malignancy diagnosed in women). Among the four major types of thyroid cancer, papillary thyroid cancer (PTC) accounts $85-90 \%$ from all thyroid cases, followed by follicular thyroid cancer (FTC) which accounts for $5-10 \%$ of cases.

Materials and Methods: A retrospective data of 260 patients who underwent thyroid surgery from 2015 to 2019 were included in the study and the status of the disease (clinical manifestations, laboratory/pathology findings (thyroid function tests (TFTs) and biopsy) were reviewed from patient cards. The pattern of thyroid cancer was discriminated based on histo-pathological biopsy result. Descriptive and analytical statistics were applied to express the finding and reported by tables, figures and narration. Cross tabulation and logistic regression was applied to determine the association between thyroid CA and predictors. A $p$-value of $<0.05$ was declared as statistically significant.

Results: From the total sample of 260 patients underwent thyroid surgery, majority of them were females $219(84.2 \%)$, belong to age interval of 31-40 years (34.6\%), dwellers of Oromia region (91.2\%) and Jimma zone (83.8\%). Colloid goiter was the most prevalent (74.6\%) pattern of thyroid disease followed by follicular CA (4.2\%), papillary CA (1.9\%) and medullary CA (0.77\%) while biopsy results of $48(18.46 \%)$ patients were not known. In general, about the 194(91.5\%) of the thyroid lesion was identified as benign type and malignancy accounts for 18(8.5\%) from the total conducted biopsy results of 212 patients. About six variables (duration of the disease, marital status, family history of the disease, nodularity, surface and border of the thyroid mass) were the candidate variables in binary logistic regression ( $p$-value $<0.25)$ and finally, three variables (duration of the disease (>10 years), surface (rough) and border (irregular) of the thyroid mass) were identified as the predictors of thyroid malignancy with AOR 0.05(0.004-0.60, $P-v=0.016$; 1.9(1.17-5.8), $P-v=0.012$ and 2.5(1.13-16.16), $P-v<0.001$ respectively.

Conclusion and recommendation: The burden of malignancy was higher and alarming among thyroid diseases and warrants early screening and management.

\section{Introduction}

Thyroid cancer (TCA) is a relatively rare disease accounting for approximately $1-2 \%$ of all cancers worldwide. However, it is the most common (95\%) endocrine malignancy associated with more deaths annually than all other endocrine cancers combined [1, 2].

The incidence of thyroid cancer has continuously and sharply increased globally due to advanced technology to detect/screen in early preclinical stage, increased gender differences and a possible consequence of increased population exposure to radiation and to other still unrecognized carcinogens [3$5]$. 
TCA commonly affects women (about 3-4 times) than men, can occur at any age but most tumors are diagnosed during the third to the sixth decades of life. It is the second and the fifth most common cancer in women in Italy and USA respectively. In USA only about 62,000 new cases occurred in men and women in $2015[6]$.

Despite, early diagnosis and better treatment of thyroid cancer, its mortality rate is increasing and in USA among patients diagnosed with thyroid cancer from 1974-2013, the overall incidence of thyroid cancer increased by $3.6 \%$ annually $[7,8]$.

A cohort study conducted in Australia among 2,260 patients underwent thyroidectomy performed over 40 years, thyroid cancer was diagnosed among 3.6 to $7.5 \%(P<0.05)$ and confirmed an increase in the incidence of thyroid cancer over 4 decades [9]. The study conducted in Turkey among patients underwent thyroidectomy reported $14 \%$ of thyroid cancer rate [10].

Most thyroid malignancies are well differentiated thyroid cancers (DTC) and have an excellent prognosis with survival rates of more than $95 \%$ at 20 years although the recurrence or persistent rate is still high [1115]. However, a notable proportion of cases are undifferentiated carcinomas and exhibit aggressive characteristics associated with a significantly higher recurrence and mortality rates [16-19].

Most primary thyroid cancers are epithelial tumors that originate from thyroid follicular (acinar) cells [2024]. The three major pathologic types of thyroid carcinomas that arise from follicular cells are: papillary thyroid carcinoma (PTC), follicular thyroid carcinoma (FTC) and anaplastic thyroid carcinoma (ATC). Medullary thyroid carcinoma (MTC) arises from thyroid para-follicular (C) cells $[11,14,25,26]$.

PTC is the most common type and it accounts for $85-90 \%$ of all thyroid cancer cases [27-30] followed by FTC which is the second common carcinoma constituting about $5-10 \%$ of all thyroid cancers [31-33]. Medullary thyroid tumors accounts about $5-10 \%$ of all thyroid carcinoma and are familial in approximately $25 \%$ of cases [34]. ATC which is an undifferentiated thyroid carcinoma accounts for less than $2 \%$ of thyroid cancers and typically diagnosed in the elderly patients and is associated with poor prognosis [35-37].

Thyroid cancer, particularly undifferentiated thyroid carcinoma, is a cause of significant mortality and morbidity. Death from differentiated thyroid carcinoma, although rare, can also occur; early diagnosis and treatment is the key for good prognosis.

\section{Methods}

The study was conducted at Jimma medical center (JMC) which is one of the known teaching referral hospitals of the country located at distance of $335 \mathrm{~km}$ from the capital of Ethiopia, Addis Ababa to southwest direction. It was established in 1930 and owned initially by Jimma health science (Jimma University currently). It provides health services for approximately 9000 in patient and 80,000 outpatient attendances per year with a very wide catchment population (about 15 million people) in southwest Ethiopia. The study was conducted from November December, 2019 by reviewing patient cards that underwent thyroid surgery from 2015 to 2019 by employing a cross-sectional study design among sampled 
260 patients. But, the histo-pathologic results of 48 patients were not available (probably not done/missed) and finally only 212 patients were analysed for pattern of CA. A structured questionnaire was used to record patient information including previous laboratory results.

Data was checked for missed values and outliers, cleaned, entered into Epidata version 4.3.1 and finally exported to SPSS version 22 for analysis. Both descriptive and analytical statistics were applied and the finding of the study was reported by tables, graphs and narration. Cross tabulation and logistic regression were applied to assess the association of outcome variable (thyroid cancer) and associated factors. P-value $<0.05$ was declared as statistically significant.

Ethical clearance was obtained from Jimma University ethical committee after the proposal was approved by Jimma University ethical review board and support letter was collected from the University and hospital. All the information obtained from the records was anonymous.

\section{Results}

\section{Socio-demographic and baseline characteristics of respondents}

Among total sample of 260 patients underwent thyroid surgery, majority of them belongs to female $219(84.2 \%)$, at age interval of $31-40$ years (34.6\%), Oromia region (91.2\%) and Jimma zone (83.8\%) as detailed in Table 1. 
Table 1

Socio-demographic and baseline characteristics of patients underwent thyroid surgery at JMC, from 2015-2019

\begin{tabular}{|c|c|c|c|}
\hline Variable & Category & Frequency & Percent (\%) \\
\hline \multirow[t]{2}{*}{ Sex } & Male & 41 & 15.8 \\
\hline & Female & 219 & 84.2 \\
\hline \multirow[t]{5}{*}{ Age } & $<20$ & 19 & 7.3 \\
\hline & $21-30$ & 73 & 28.1 \\
\hline & $31-40$ & 90 & 34.6 \\
\hline & $41-50$ & 41 & 15.8 \\
\hline & $>51$ & 37 & 14.2 \\
\hline \multirow[t]{4}{*}{ Marital status } & Single & 57 & 21.9 \\
\hline & Married & 195 & 75.0 \\
\hline & Divorced & 2 & 0.8 \\
\hline & Widowed & 6 & 2.3 \\
\hline \multirow[t]{2}{*}{ Region } & Oromia & 237 & 91.2 \\
\hline & SNNP & 23 & 8.8 \\
\hline \multirow[t]{5}{*}{ Zone } & Jimma & 218 & 83.8 \\
\hline & Bedelle & 9 & 3.5 \\
\hline & Ilu Abbabor & 10 & 3.8 \\
\hline & Bonga & 14 & 5.4 \\
\hline & Mizan Tepi & 9 & 3.5 \\
\hline \multirow[t]{4}{*}{ Duration of illness in years } & $<1$ & 24 & 9.2 \\
\hline & $1-5$ & 105 & 40.4 \\
\hline & $6-10$ & 91 & 35.0 \\
\hline & $>10$ & 40 & 15.4 \\
\hline
\end{tabular}

\section{Clinical profile of thyroid patients}

The clinical profile of thyroid disease was recorded/ retrieved from patient cards including patient history, physical examination, laboratory results (T3, T4 and TSH) and pathologic results (FNAC and biopsy) as seen in Table 2. 
Table 2

Clinical Characteristics and Diagnosis of Patients Operated for Thyroid Lesions in JMC from 20152019

\begin{tabular}{|c|c|c|c|}
\hline Variable & Category & Frequency & Percent (\%) \\
\hline \multirow[t]{4}{*}{ Duration of illness in years } & $<1$ & 24 & 9.2 \\
\hline & $1-5$ & 105 & 40.4 \\
\hline & $6-10$ & 91 & 35.0 \\
\hline & $>10$ & 40 & 15.4 \\
\hline \multirow[t]{2}{*}{ Pain } & Painless & 255 & 98.1 \\
\hline & Painful & 5 & 1.9 \\
\hline \multirow[t]{2}{*}{ Voice change } & Yes & 8 & 3.1 \\
\hline & No & 252 & 96.9 \\
\hline \multirow[t]{2}{*}{ Dyspnea } & Yes & 113 & 43.5 \\
\hline & No & 147 & 56.5 \\
\hline \multirow[t]{2}{*}{ Dysphagia } & Yes & 4 & 1.5 \\
\hline & No & 256 & 98.5 \\
\hline \multirow[t]{2}{*}{ Family history of the thyroid disease } & Yes & 93 & 35.8 \\
\hline & No & 167 & 62.2 \\
\hline \multirow[t]{2}{*}{ History of smoking } & Yes & 3 & 1.2 \\
\hline & No & 257 & 98.8 \\
\hline \multirow[t]{2}{*}{ Previous radiation exposure } & Yes & 0 & 0.0 \\
\hline & No & 260 & 100.0 \\
\hline \multirow[t]{3}{*}{ Size of the swelling (longest diameter in $\mathrm{cm}$ ) } & $<5$ & 33 & 12.7 \\
\hline & $6-10$ & 86 & 33.1 \\
\hline & $>10$ & 141 & 54.2 \\
\hline \multirow[t]{2}{*}{ Border of the mass } & Regular & 238 & 91.5 \\
\hline & Irregular & 22 & 8.5 \\
\hline \multirow[t]{2}{*}{ Nodularity } & Simple nodular & 192 & 73.8 \\
\hline & Multinodular & 68 & 26.2 \\
\hline \multirow[t]{2}{*}{ Consistency } & Soft & 53 & 20.4 \\
\hline & Firm & 200 & 76.9 \\
\hline
\end{tabular}




\begin{tabular}{|c|c|c|c|}
\hline Variable & Category & Frequency & Percent (\%) \\
\hline & Hard & 7 & 2.7 \\
\hline \multirow[t]{2}{*}{ Surface } & Smooth & 237 & 91.2 \\
\hline & Rough & 23 & 8.8 \\
\hline \multirow[t]{3}{*}{ TSH } & Low & 13 & 5.0 \\
\hline & Normal & 244 & 93.8 \\
\hline & High & 3 & 1.2 \\
\hline \multirow[t]{3}{*}{ T3 } & Low & 2 & 0.8 \\
\hline & Normal & 258 & 99.2 \\
\hline & High & 0 & 0.0 \\
\hline \multirow[t]{3}{*}{ T4 } & Low & 1 & 0.4 \\
\hline & Normal & 259 & 99.6 \\
\hline & High & 0 & 0.0 \\
\hline \multirow[t]{3}{*}{ Metastasis } & LAP & 4 & 1.5 \\
\hline & Bone & 8 & 3.1 \\
\hline & Lung & 0 & 0.0 \\
\hline \multirow[t]{5}{*}{ FNAC result } & Colloid goiter & 235 & 91.2 \\
\hline & Papillary CA & 7 & 2.7 \\
\hline & Follicular neoplasm & 13 & 5.0 \\
\hline & Medullary CA & 2 & 0.8 \\
\hline & Others (hyperplastic) & 1 & 0.4 \\
\hline \multirow[t]{5}{*}{ Biopsy result } & Colloid goiter & 194 & 74.6 \\
\hline & Papillary CA & 5 & 1.9 \\
\hline & Follicular CA & 11 & 4.2 \\
\hline & Medullary CA & 2 & 0.8 \\
\hline & Not applicable & 48 & 18.5 \\
\hline
\end{tabular}

\subsection{Pattern of thyroid diseases by histopathology results}

Colloid goiter was the most prevalent (74.6\%) pattern of thyroid disease followed by follicular CA $(4.2 \%)$, papillary CA $(1.9 \%)$ and medullary CA $(0.77 \%)$. But, biopsy results of $18.46 \%$ patients were not known. In 
general from total patients of 212 who had biopsy results, the burden of benign and malignancy accounted for $91.5 \%$ and $8.5 \%$ respectively (Fig. 1).

\subsection{Association of thyroid diseases with other variables}

Logistic regression was applied to evaluate the associated factors of thyroid malignancy based on histopathological biopsy result. Accordingly, about six variables (duration of the disease, marital status, family history of the disease, nodularity, surface and border of the thyroid mass) were the candidate variables in binary logistic regression ( $p$-value $<0.25$ ) and finally, three variables (duration of the disease (> 10 years), surface (rough) and border (irregular) of the thyroid mass) were identified as the predictors of thyroid malignancy with AOR 0.05(0.004-0.60, $\mathrm{P}-\mathrm{v}=0.016 ; 1.9(1.17-5.8), \mathrm{P}-\mathrm{v}=0.012$ and 2.5(1.13-16.16), $\mathrm{P}-\mathrm{v}<0.001$ respectively as detailed in Table 4 . 
Table 4

Association of status thyroid lesion with other predictors among Patients Operated for Thyroid Lesions in JMC from 2015-2019

\begin{tabular}{|c|c|c|c|c|c|c|c|}
\hline \multirow[t]{2}{*}{ Variable } & \multirow[t]{2}{*}{ Category } & \multicolumn{6}{|c|}{ Status of thyroid lesion; No (\%) } \\
\hline & & Benign & Malignancy & $\operatorname{COR}(\mathrm{Cl})$ & $\begin{array}{l}\mathrm{P}- \\
\text { value }\end{array}$ & $\mathrm{AOR}(\mathrm{Cl})$ & $\begin{array}{l}\mathrm{P}- \\
\text { value }\end{array}$ \\
\hline \multirow[t]{2}{*}{ Age } & $<30$ & $70(33.0)$ & $5(2.4)$ & 1 & & - & - \\
\hline & $\geq 30$ & $124(58.5)$ & $13(6.1)$ & $\begin{array}{l}1.5(0.5- \\
4.3)\end{array}$ & 0.483 & - & - \\
\hline \multirow[t]{2}{*}{ Sex } & Male & $32(15.1)$ & $2(0.9)$ & 1 & & - & - \\
\hline & Female & 162(76.4) & $16(7.5)$ & $\begin{array}{l}1.6(0.4- \\
7.2)\end{array}$ & 0.555 & - & - \\
\hline \multirow[t]{2}{*}{ Region } & Oromia & $175(82.5)$ & $17(8.0)$ & $\begin{array}{l}1.8(0.2- \\
14.6)\end{array}$ & 0.562 & - & - \\
\hline & SNNP & $19(9.0)$ & $1(0.5)$ & 1 & & - & - \\
\hline \multirow[t]{2}{*}{ Zone } & Jimma & $160(75.5)$ & $13(6.1)$ & $\begin{array}{l}0.6(0.2- \\
1.6)\end{array}$ & 0.289 & - & - \\
\hline & Others & $34(16.0)$ & $5(2.4)$ & 1 & & - & - \\
\hline \multirow[t]{2}{*}{$\begin{array}{l}\text { Marital } \\
\text { status }\end{array}$} & Married & $146(68.9)$ & $17(8.0)$ & $\begin{array}{l}5.6(0.7- \\
43.1)\end{array}$ & $0.099 *$ & $\begin{array}{l}5.4(0.5- \\
55)\end{array}$ & 0.158 \\
\hline & Others & $48(22.6)$ & $1(0.5)$ & 1 & & 1 & \\
\hline \multirow{4}{*}{$\begin{array}{l}\text { Duration of } \\
\text { illness in } \\
\text { years }\end{array}$} & $<1$ & $17(8.0)$ & $4(1.9)$ & 1 & & 1 & $24(9.2)$ \\
\hline & $1-5$ & $76(35.8)$ & $7(3.3)$ & $\begin{array}{l}0.4(0.1- \\
1.5)\end{array}$ & $0.169 *$ & $\begin{array}{l}0.4(0.06- \\
2.2)\end{array}$ & 0.280 \\
\hline & $6-10$ & $69(32.5)$ & $4(1.9)$ & $\begin{array}{l}0.3(0.05- \\
0.9)\end{array}$ & $0.064^{*}$ & $\begin{array}{l}0.08(0.009- \\
0.7)\end{array}$ & $0.022 *$ \\
\hline & $>10$ & $32(15.1)$ & $3(1.4)$ & $\begin{array}{l}0.4(0.08- \\
1.9)\end{array}$ & $0.242^{*}$ & $\begin{array}{l}0.05(0.004- \\
0.6)\end{array}$ & $0.016 *$ \\
\hline \multirow[t]{2}{*}{$\begin{array}{l}\text { Voice } \\
\text { change }\end{array}$} & Yes & $7(3.3)$ & $1(0.5)$ & $\begin{array}{l}1.6(0.2- \\
13.5)\end{array}$ & 0.681 & - & - \\
\hline & No & 187(88.2) & $17(8.0)$ & 1 & & - & \\
\hline \multirow[t]{2}{*}{ Dyspnea } & Yes & $83(39.2)$ & $9(4.2)$ & $\begin{array}{l}1.3(0.5- \\
3.5)\end{array}$ & 0.556 & - & - \\
\hline & No & $111(52.4)$ & $9(4.2)$ & 1 & & - & - \\
\hline $\begin{array}{l}\text { Family } \\
\text { history }\end{array}$ & Yes & $70(33.0)$ & $4(1.9)$ & $\begin{array}{l}0.5(0.2- \\
1.6)\end{array}$ & $0.245^{*}$ & $\begin{array}{l}1.5(0.3- \\
7.4)\end{array}$ & 0.617 \\
\hline
\end{tabular}

*-statistically significant; Others- explained in Table 1 for all variables 


\begin{tabular}{|c|c|c|c|c|c|c|c|}
\hline & No & $124(58.5)$ & $14(6.6)$ & 1 & & 1 & \\
\hline \multirow{3}{*}{$\begin{array}{l}\text { Size of neck } \\
\text { swelling in } \\
\mathrm{cm}\end{array}$} & $<5$ & $22(10.4)$ & $1(0.5)$ & 1 & & - & - \\
\hline & $6-10$ & $63(29.7)$ & $7(3.3)$ & $\begin{array}{l}2.4(0.3- \\
21)\end{array}$ & 0.415 & - & - \\
\hline & $>10$ & $109(51.4)$ & $10(4.7)$ & $\begin{array}{l}2.0(0.3- \\
16.6)\end{array}$ & 0.513 & - & - \\
\hline \multirow[t]{2}{*}{ Nodularity } & Simple nod. & 149(70.3) & $11(5.2)$ & 1 & & 1 & \\
\hline & Multinodule & $45(14.2)$ & $3(1.4)$ & $\begin{array}{l}2.1(0.8- \\
5.8)\end{array}$ & $0.146 *$ & $\begin{array}{l}2.3(0.5- \\
9.7)\end{array}$ & 0.266 \\
\hline \multirow[t]{2}{*}{ Consistency } & Soft & $30(18.8)$ & $3(1.4)$ & 1 & & 1 & \\
\hline & Others & 164(77.4) & $15(7.1)$ & $\begin{array}{l}1.1(0.2- \\
3.3)\end{array}$ & 0.893 & - & - \\
\hline \multirow[t]{2}{*}{ Surface } & Smooth & 186(87.7) & $9(4.2)$ & 1 & & 1 & \\
\hline & Rough & $8(3.8)$ & $9(4.2)$ & $\begin{array}{l}2.3(1.2- \\
7.4)\end{array}$ & ¿. $001 *$ & $\begin{array}{l}1.9 .(1.17- \\
5.8)\end{array}$ & $0.012^{*}$ \\
\hline \multirow[t]{2}{*}{ Border } & Regular & 187(88.2) & $7(3.3)$ & 1 & & 1 & \\
\hline & Irregular & $7(3.3)$ & $11(5.2)$ & $\begin{array}{l}4.2(1.2- \\
14.1)\end{array}$ & <.001* & $\begin{array}{l}2.5(1.13- \\
16.16)\end{array}$ & $0.001 *$ \\
\hline
\end{tabular}

\section{Discussion}

Among total sample of 260 patients underwent thyroid surgery, majority of them were female $219(84.2 \%)$ with male to female ratio of $1: 5.3$, dominant age interval of $31-40$ years (34.6\%) while the distribution is in harmony with other studies [27-29].

In general, from total patients who had biopsy results of 212 , about $194(81.5 \%)$ of patients were diagnosed for benign type of thyroid lesion while malignancy accounted for $8.5 \%$ where this finding was also supported by other studies that reported similar pattern [30, 31].

Among 18 patients diagnosed with malignancy, follicular CA was the commonest $11(61.1 \%)$ followed by papillary CA $5(27.7 \%)$ and medullary CA $2(1.1 \%)$. The pattern of CA of thyroid lesion in the present study was in agreement with different studies that reported dominance of follicular CA [32-35]. But, the finding was against other studies [36-40] that witnessed the dominance of papillary CA. The difference in pattern of thyroid CA was negotiated by review study of Ogbera and Kuku that justified as a changing trend toward the more frequent occurrence of papillary CA compared to follicular CA may be attributable to widespread iodization programs [41]. 
Finally, three variables (short duration of the disease, rough surface and irregular border of the thyroid mass) were associated with thyroid malignancy ( $p$-value $<0.05$ ) which was also in agreement with other studies $[42,43]$. Even though smoking was associated with the thyroid CA, it was not statistically significant in the present study against study conducted in Korea that revealed age, residence, belief in cancer screening, regular health check-ups, smoking, alcohol drinking, and exercise were associated with thyroid cancer screening [44]. The study by Haymart et al [45] reported that likelihood of thyroid cancer increases with higher serum TSH concentration in contrast to the present study probably due to screening modality and population difference.

\section{Conclusion}

In general, about the $81.5 \%$ of the thyroid lesion was identified as benign type while malignancy accounted for $8.5 \%$ from a total of 212 biopsy result analyzed for CA pattern. Among malignancy, follicular CA was the commonest (4.2\%) among thyroid lesion patients underwent thyroidectomy. Short duration of the disease, rough surface and irregular border of the thyroid mass were identified as the predictors of thyroid malignancy.

\section{Declarations}

\section{Ethics approval and consent to participate}

Ethical clearance was obtained from Jimma University ethical committee after the proposal was approved by Jimma University ethical review board and support letter was collected from the University and hospital. All the information obtained from the records was anonymous.

\section{Consent to publish}

Not applicable.

\section{Availability of data and materials}

Needed materials can be provided upon request of corresponding author.

\section{Conflict of interests}

The authors declared that there is not conflict of interests.

\section{Funding}

Jimma University provided funding as post graduate research in 2019 for data collection. 


\section{Author contribution}

Conceptualization, BM, YM and SA; Data curation, BM, YM, SA and WRD; Formal analysis, BM and WRD; Funding acquisition, BM; Investigation, BM; Methodology, BM, YM, SA and WRD; Resources, BM.; Software, BM and WRD; Supervision, YM, SA and WRD; Validation, BM, YM, SA and WRD; Visualization, BM, YM, SA and WRD; Writing original draft, BM and WRD; Writing-review and editing:, BM, YM, SA and WRD. All authors have read and agreed to the developed manuscript.

\section{Acknowledgement}

The authors would like to thank Jimma University for providing funding, and all data collectors and study participants.

\section{References}

1. Cossu A, Budroni M, Paliogiannis P, Palmieri G, Scognamillo F, Cesaraccio R, et al. Epidemiology of thyroid cancer in an area of epidemic thyroid goiter. Journal of cancer epidemiology. 2013;2013.

2. Sipos JA, Mazzaferri EL. Thyroid cancer epidemiology and prognostic variables. Clin Oncol (R Coll Radiol). 2010;22:395-404.

3. Pellegriti G, Frasca F, Regalbuto C, Squatrito S, Vigneri R. Worldwide increasing incidence of thyroid cancer: update on epidemiology and risk factors. Journal of cancer epidemiology. 2013;2013.

4. Kilfoy BA, Zheng T, Holford TR, Han X, Ward MH, Sjodin A, et al. International patterns and trends in thyroid cancer incidence, 1973-2002. Cancer Causes Control. 2009;20:525-31.

5. Davies L, Welch HG. Increasing incidence of thyroid cancer in the United States, 1973-2002. JAMA. 2006;295:2164-7.

6. Cabanillas ME, McFadden DG, Durante C. Thyroid cancer. The Lancet. 2016;388:2783-2795.

7. Lim H, Devesa SS, Sosa JA, Check D, Kitahara CM. Trends in thyroid cancer incidence and mortality in the United States, 1974-2013. Jama. 2017;317:1338-1348.

8. Hershman JM. Thyroid Cancer incidence and mortality are increasing. Clinical Thyroidology. 2017;29:221-223.

9. Grodski S, Brown T, Sidhu S, Gill A, Robinson B, Learoyd D, et al. Increasing incidence of thyroid cancer is due to increased pathologic detection. Surgery. 2008;144:1038-1043.

10. Taşova V, Kilicoglu B, Tuncal S, Uysal E, Sabuncuoglu MZ, Tanrikulu Y, et al. Evaluation of incidental thyroid cancer in patients with thyroidectomy. West Indian Medical Journal. 2013;62:844-848.

11. Katoh H, Yamashita K, Enomoto T, Watanabe M. Classification and general considerations of thyroid cancer. Ann Clin Pathol. 2015;3:1045.

12. Kebebew E, Clark OH. Differentiated thyroid cancer:"complete" rational approach. World Journal of Surgery. 2000;24:942-951. 
13. Schneider TC, Abdulrahman RM, Corssmit EP, Morreau H, Smit JWA, Kapiteijn E. Long-term analysis of the efficacy and tolerability of sorafenib in advanced radio-iodine refractory differentiated thyroid carcinoma: final results of a phase II trial. European journal of endocrinology. 2012;167:643.

14. Schneider DF, Chen $\mathrm{H}$. New developments in the diagnosis and treatment of thyroid cancer. CA: a cancer journal for clinicians. 2013;63:373-394.

15. Caron NR, Clark OH. Well differentiated thyroid cancer. Scandinavian journal of surgery. 2004;93:261271.

16. Tang LH, Aydin H, Brennan MF, Klimstra DS. Clinically aggressive solid pseudopapillary tumors of the pancreas: a report of two cases with components of undifferentiated carcinoma and a comparative clinicopathologic analysis of 34 conventional cases. The American journal of surgical pathology. 2005;29:512-519.

17. Battafarano RJ, Fernandez FG, Ritter J, Meyers BF, Guthrie TJ, Cooper JD, et al. Large cell neuroendocrine carcinoma: an aggressive form of non-small cell lung cancer. The Journal of thoracic and cardiovascular surgery. 2005;130:166-172.

18. Sywak M, Pasieka JL, Ogilvie T. A review of thyroid cancer with intermediate differentiation. Journal of surgical oncology. 2004;86:44-54.

19. Penna GC, Vaisman F, Vaisman M, Sobrinho-Simões M, Soares P. Molecular markers involved in tumorigenesis of thyroid carcinoma: focus on aggressive histotypes. Cytogenetic and genome research. 2016;150:194-207.

20. Spiro RH, Huvos AG, Strong EW. Acinic cell carcinoma of salivary origin. A clinicopathologic study of 67 cases. Cancer. 1978;41:924-935.

21. Ward GE, Hendrick JW, Chambers RG. Carcinoma of the thyroid gland. Annals of surgery. 1950;131:473.

22. Kebebew E, Peng M, Treseler PA, Clark OH, Duh Q-Y, Ginzinger D, et al. Id1 gene expression is upregulated in hyperplastic and neoplastic thyroid tissue and regulates growth and differentiation in thyroid cancer cells. The Journal of Clinical Endocrinology \& Metabolism. 2004;89:6105-6111.

23. Fisher ER, Kim WS. Primary clear cell thyroid carcinoma with squamous features. Cancer. 1977;39:2497-2502.

24. Anscombe AM, Wright DH. Primary malignant lymphoma of the thyroid-a tumour of mucosa-associated lymphoid tissue: review of seventy-six cases. Histopathology. 1985;9:81-97.

25. Burgess JR. Temporal trends for thyroid carcinoma in Australia: an increasing incidence of papillary thyroid carcinoma (1982-1997). Thyroid. 2002;12:141-149.

26. Brown RL, de Souza JA, Cohen EE. Thyroid cancer: burden of illness and management of disease. Journal of Cancer. 2011;2:193.

27. Park HJ, Choe B-K, Kim SK, Park H-K, Kim JW, Chung J-H, et al. Association between collagen type XI a1 gene polymorphisms and papillary thyroid cancer in a Korean population. Experimental and therapeutic medicine. 2011;2:1111-1116.

28. Kim YO, Hong IK, Eun YG, Nah S-S, Lee S, Heo S-H, et al. Polymorphisms in bone morphogenetic protein 3 and the risk of papillary thyroid cancer. Oncology letters. 2013;5:336-340. 
29. Pellegriti G, Scollo C, Lumera G, Regalbuto C, Vigneri R, Belfiore A. Clinical behavior and outcome of papillary thyroid cancers smaller than $1.5 \mathrm{~cm}$ in diameter: study of 299 cases. J Clin Endocrinol Metab. 2004;89:3713-20.

30. Krawczyk-Rusiecka K, Wojciechowska-Durczyńska K, Cyniak-Magierska A, Adamczewski Z, Gałecka E, Lewiński A. COX-2 expression in papillary thyroid carcinoma (PTC) in cytological material obtained by fine needle aspiration biopsy (FNAB). Thyroid Res. 2011;4:3.

31. Banzal S, Singhai A, Shekhawat B, Raman PG. Pattern of thyroid carcinoma in Gizan region of Saudi Arabia. Thyroid Research and Practice. 2014;11:108.

32. Yilmazlar S, Kocaeli H, Cordan T. Sella turcica metastasis from follicular carcinoma of thyroid. Neurological research. 2004;26:74-78.

33. Milas ZL, Brainard J, Milas M. Thyroid cancer: classification and cytological diagnosis. Future Medicine; 2013.

34. Medullary thyroid carcinoma - Leboulleux - 2004 - Clinical Endocrinology - Wiley Online Library. https://onlinelibrary.wiley.com/doi/full/10.1111/j.1365-2265.2004.02037.x

35. Guerra A, Di Crescenzo V, Garzi A, Cinelli M, Carlomagno C, Tonacchera M, et al. Genetic mutations in the treatment of anaplastic thyroid cancer: a systematic review. BMC Surg. 2013;13 Suppl 2:S44.

36. Roche B, Larroumets G, Dejax C, Kwiatkowsi F, Desbiez F, Thieblot P, et al. Epidemiology, clinical presentation, treatment and prognosis of a regional series of 26 anaplastic thyroid carcinomas (ATC). Comparison with the literature. Ann Endocrinol (Paris). 2010;71:38-45.

37. Nagaiah G, Hossain A, Mooney CJ, Parmentier J, Remick SC. Anaplastic Thyroid Cancer: A Review of Epidemiology, Pathogenesis, and Treatment. Journal of Oncology. 2011; https://www.hindawi.com/journals/jo/2011/542358/

\section{Figures}




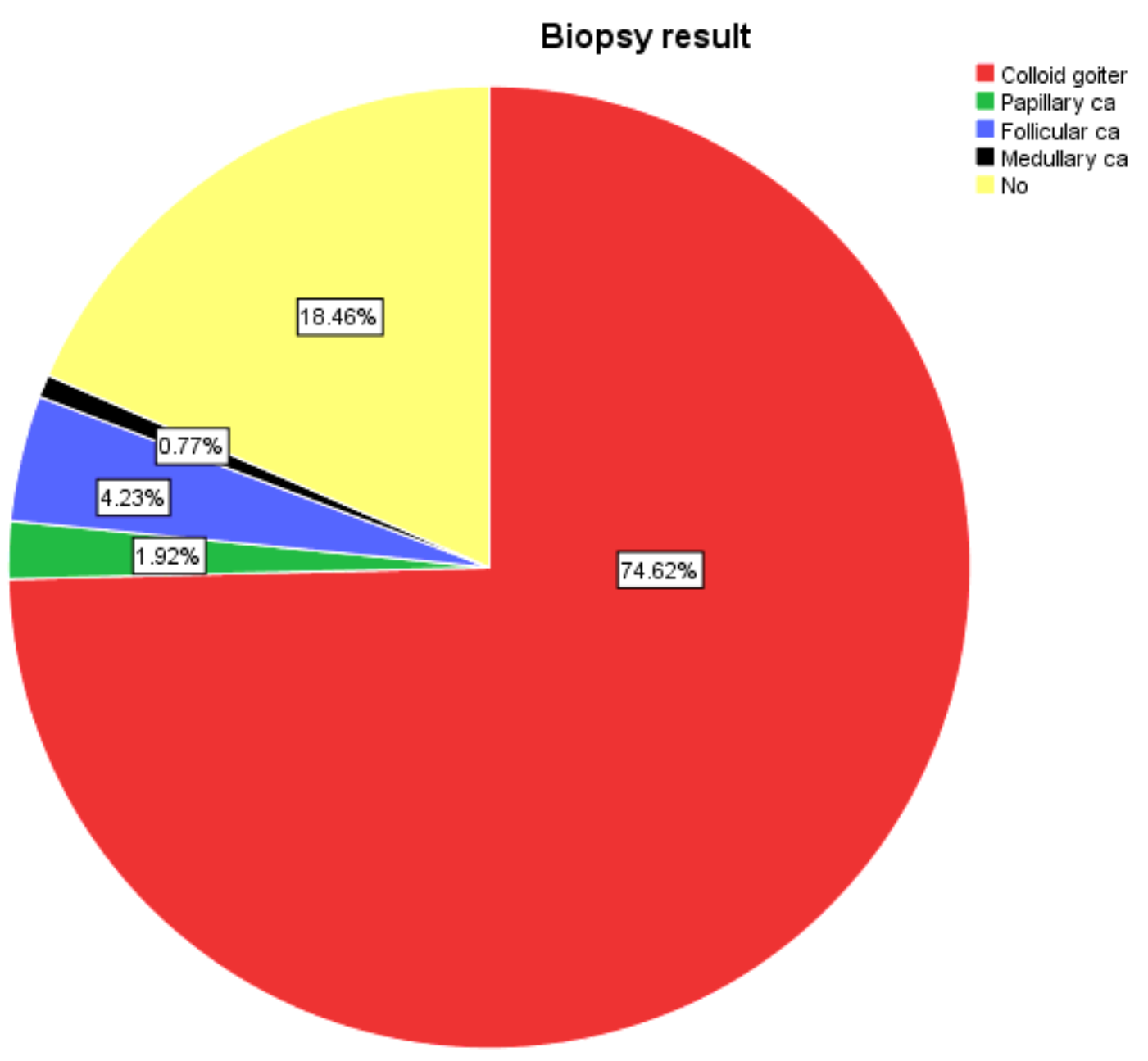

\section{Figure 1}

Biopsy result showing pattern of thyroid disease among Patients Operated for Thyroid Lesions in JMC from 2015-2019 